Review - Pregledni rad

UDK: 637.352

\title{
White cheeses as a potential source of bioactive peptides
}

\author{
doi: $10.15567 /$ mljekarstvo.2017.0101 \\ Miroljub Baraćc ${ }^{*}$, Mirjana Pešić ${ }^{1}$, Tanja Vučić ${ }^{1}$, Milena Vasić ${ }^{1}$, Milenko Smiljanić ${ }^{2}$ \\ ${ }^{1}$ University of Belgrade, Faculty of Agriculture, Nemanjina 6, Belgrade, Serbia \\ ${ }^{2}$ University of East Sarajevo, Faculty of Technology, Karakaj bb, Zvornik, Bosnia and Herzegovina
}

Received - Prispjelo: 27.05.2016. Accepted - Prihvaćeno: 25.01.2017.

\begin{abstract}
In addition to the nutritional value, cheese and other fermented milk-based products are a good source of biologically active proteins and peptides. Bioactive peptides in cheese are mainly formed during cheese production, especially during ripening, which is one of the most important stages in cheese production. Since the ripening process differ significantly depending on the cheese type, it can be assumed that their bioactivity is also substantially different. White brined cheeses are specific for the region of South-Eastern Europe. They are characterized by relatively intensive proteolysis and as such may be of interest as products with favorable functional characteristics. Yet, their functionality is still insufficiently characterized. This paper presents an overview of the current knowledge on white brined cheese's bioactive peptides.
\end{abstract}

Key words: bioactive peptides, white cheese in brine, proteolysis

\section{Introduction}

From the nutritional point of view cheese is a good source of essential substances such as proteins, vitamins, minerals and short chain fatty acids. Cheese and other fermented milk-based products contain a great number of bioactive proteins and peptides. Bioactive peptides (biologically active peptides) are defined as specific protein fragments that have positive impact on human and can ultimately affect their health (Kitts and Weiler, 2003). Although some bioactive proteins and peptides originate from milk itself, the largest part is formed during cheese production, especially during ripening or proteolysis (Corrêa et al., 2011; Pattom and Hongsprabhas, 2013; Power et al., 2013). Bioactive peptides are mainly fragments containing 2-20 amino acid residues which exhibit variety of activities including immunomodulatory, antihypertensive, antimicrobial, antioxidant and opioid activity (Korhonen, 2009; Nagpal et al., 2011;
Phelan and Kerins, 2011; López-Expósito et al., 2012; Baum et al., 2013; Pisanu et al., 2015). Figure 1. presents an overview of currently known forms of peptide bioactivity in milk and milk products. Bioactive peptides contained in fermented milk products are mainly derived from casein hydrolysis by proteases and peptidases originating from milk, rennet, starter- and non-starter bacteria (Sieber et al., 2010; Sahingil et al., 2014). Besides caseins, whey proteins and their proteolytic products also exert bioactivity (Korhonen et al., 1998; Lisak-Jakopović et al., 2016). The degree of bioactive peptides formation is determined by a number of factors such as type of milk, heat treatment, ripening conditions and stage of ripening (G agnaire et al., 2011; Sanhingil et al., 2014; Gomez-Ruiz et al., 2007; Pritchard et al., 2010; Sforza et al., 2003, 2012; Korhonen and Marnila, 2013). Thus, the presence of bioactive peptides is determined by type and characteristics of cheese. 
White cheese in brine is a type of cheese that is mostly produced and consumed in the countries of the South-Eastern Europe. It is usually prepared in artisanal way from raw or heat-treated milk. These cheeses are mostly produced from cow milk, and to a lesser extent from sheep or goat milk. The specificity of this type of cheese is ripening that takes place in brine usually within 2-3 months. They are characterized by relatively intensive proteolysis during which a broad range of low molecular weight peptides of different bioactivity are formed. Nevertheless, bioactivity of peptides found in white brined cheese is still not sufficiently characterized. This paper presents an overview of the current knowledge of bioactive peptides from white brined cheeses.

\section{Proteins of white cheese in brine}

White brined cheeses, as well as other cheese types are products whose main components are proteins and milk fat. The content of these components varies and is determined by numerous factors such as milk type and composition, milk pre-treatment, heat treatment and ripening conditions (Maćej et al., 2007). In general, cheeses are a source of highly nutritive, almost $100 \%$ digestible proteins (López-Expósito et al., 2012). The protein content in white cheeses is variable and ranges up to approximately $28 \%$ (Hayaloglu et al., 2008; Dozet, 2004). The largest part of cheese matrix proteins are caseins, $\alpha s^{-}, \beta$ - and $\kappa$-caseins. In the available literature there is data characterizing the structure and properties of casein (Maćej et al., 2007). As a result of different resistance of dominant caseins (CN) $\alpha_{\mathrm{s}}-\mathrm{CN}$ and $\beta-\mathrm{CN}$ during proteolysis (Fox et al., 1993; Sarantinopoulos et al., 2002) the share of individual caseins in white cheeses in brine has dynamic character and is determined by ripening stage. Generally, $\alpha_{\mathrm{s}}-\mathrm{CN}$ are more susceptible to proteolysis and ripened traditional white cheese in brine (60-90 days) contains $30 \%-40 \%$ residual $\alpha_{s}-\mathrm{CN}$ and $85-90 \%$ residual $\beta-\mathrm{CN}$ (Alichanidis and Polychronidau, 2008).

Besides caseins, whey proteins (WP) such as $\alpha$-La, $\beta$-Lg, and other less represented proteins participate in white cheese protein matrix. However, their content in cheese is much lower since most of them are lost during production. In traditional production process of autochthonous white cheeses most of whey proteins are lost through whey and are present in cheese in trace amounts (Barać et al., 2006, 2013; Smiljanić et al., 2014). Low level of these proteins is registered in white cheeses made from milk which is heat-treated at moderate temperatures $\left(63-70{ }^{\circ} \mathrm{C}\right.$ ) (Korhonen and Marnila, 2013). On the other hand, by overheating milk at temperatures above $80{ }^{\circ} \mathrm{C}$ large part of whey proteins is incorporated into the protein matrix, which is a result of chemical interaction between $\mathrm{CN}$ and WP, and between WP themselves, and the formation of the so-called WP-CN complex (Jovanović et al., 2005a,b; Pesic et al., 2011, 2012a). The degree of their incorporation is determined by the heat treatment regime (temperature and time) and the type of milk (Vasbinder and de Kruif, 2003; Chevalier et al., 2009; Pesic et al., 2012b, 2014). Applying heat treatment of goat and cow milk at $90{ }^{\circ} \mathrm{C}$ for $10 \mathrm{~min}$, over $90 \%$ of the initial amount of whey proteins would be incorporated into complexes (Pesic et al., 2012b, 2014, 2015), while the protein extracts of white cheeses made from such milk would contain more than $12 \%$ of dominant whey proteins ( $\alpha$-La and $\beta$ - $\mathrm{Lg}$ ), as well as minor whey proteins such as lactoferrin and immunoglobulin (Barac et al., 2016 a, b).

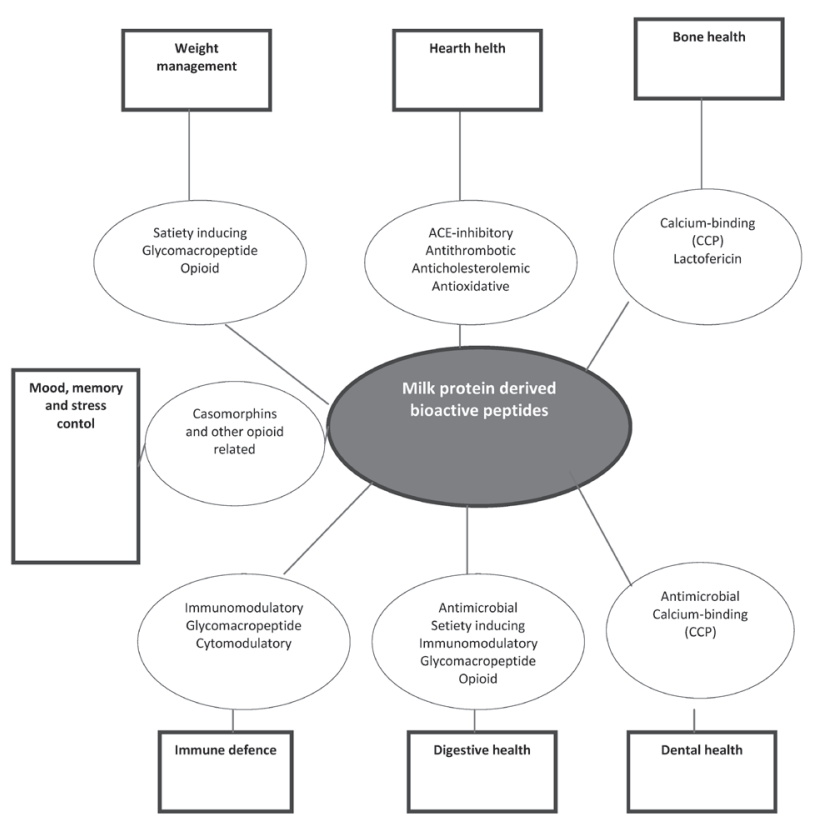

Figure 1. Bioactivity of milk protein-derived peptides and their influence on human health (Korhonen, 2009) 
Both types of cheese proteins exert biological activity (Power et al., 2013; Korhonen and Marnila, 2013; Zulueta et al., 2009). However, they are largely precursors of low molecular weight peptides which are released under the action of proteolytic enzymes during gastrointestinal digestion, proteolysis in cheese ripening (De Simone et al., 2009), and to a lesser extent during the heat treatment of milk (Parrela et al., 2012).

According to the current knowledge, bioactive peptides are small peptides containing up to 20 amino acids. Mostly they originate from $\alpha_{\mathrm{s} 1} \mathrm{CN}$, followed by $\beta-\mathrm{CN}$ and $\alpha_{\mathrm{s} 2}-\mathrm{CN}$, while $\kappa-\mathrm{CN}$ is a minor source of these peptides (Baum et al., 2013). Numerous authors including Fitzgerald and Meisel (1999), De Simone et al. (2009), Zulueta et al. (2009), Çekiç et al. (2015) showed that hydrolysis of dominant whey proteins $(\alpha-\mathrm{La}$ and $\beta-\mathrm{Lg})$ produces peptides which exhibit different bioactivity, including ACE-inhibitory and antioxidant activity.

\section{Bioactive proteins and peptides of cheese}

For many years it has been known that both types of proteins present in milk and dairy products, caseins and whey proteins have biological activity. For example, milk contains lysozyme, lactoferrin, immunoglobulins, hormones, cytokines and growth factors, secreted in their active form by mammary glands and exerting bioactivities. Furthermore, it is known that caseins exert antioxidant properties. Some characteristics of bioactive milk proteins are given in Table 1 . In addition, research conducted over the last 20 years have shown that milk and fermented dairy products, which include different types of cheese, are a potential source of bioactive peptides with antihypertensive, immunomodulatory, antimicrobial and antioxidant activity, and can be important in prevention and treatment of various diseases.

\section{Antihypertensive peptides}

Hypertension is a huge problem in the developed world countries and about $30 \%$ of adult population suffers from it (López-Expósito, 2012). It is closely associated with coronary heart disease. The antihypertensive effect of milk proteins and products of their proteolysis represents the initial subject of research in the field of peptide bioactivity. Nowadays it is considered that proteins and dairy products are one of the most important source of such bioactive peptides (Phelan and Kerins 2011; Hernández-Ledesma et al., 2011). The initial research in the field of antihypertensive peptides referred to detection and characterization of peptides obtained by milk fermentation which inhibit angiotensin-converting enzyme (ACE, EC 3.4.15.1)

Table 1. Biological activity of major milk proteins (Korhonen et al., 1998; Korhonen and Philanto, 2006)

\begin{tabular}{ccc}
\hline Protein & $\begin{array}{c}\text { Concentration } \\
\mathrm{g} / \mathrm{L}\end{array}$ & Function \\
\hline Caseins $(\alpha, \beta, \kappa)$ & 28 & $\begin{array}{c}\text { Ion carrier }(\mathrm{Ca}, \mathrm{Fe}, \mathrm{Zn}, \mathrm{Cu}) ; \\
\text { precusors of bioactive peptides }\end{array}$ \\
\hline$\beta$-lactoglobulin & 1.3 & $\begin{array}{c}\text { Retinol carrier, fatty acid binding, } \\
\text { possible antioxidant }\end{array}$ \\
\hline$\alpha$-lactalbumin & 1.2 & $\begin{array}{c}\text { Lactose synthesis in mammary gland, Ca carrier, } \\
\text { immunomodulation, anticarcinogenic }\end{array}$ \\
\hline Immunoglobulins A, M and G & 0.7 & Immune protection \\
\hline Glycomacropeptide & 1.2 & Antiviral, bifidogenic \\
\hline Lactoferrin (LF) & 0.1 & $\begin{array}{c}\text { Antimicrobial, antioxidative, immunomodulation, } \\
\text { iron absorption, anticarcinogenic }\end{array}$ \\
\hline Lactoperoxidase & 0.03 & Antimicrobial \\
\hline Lysozyme & 0.0004 & $\begin{array}{c}\text { Antimicrobial, synergistic effects } \\
\text { with immunoglobulis and LF }\end{array}$ \\
\hline
\end{tabular}


(Otte et al., 2007). This enzyme plays a role in the rennin-angiotensin system (Fig. 2) by converting angiotensin I to a potent vasoconstrictor, angiotensin II, which also induces the release of aldosterone and therefore increases the sodium concentration and blood pressure. ACE also takes part of the kinin-kalicrein system as it hydrolyzes bradykinin, which has a vasodilator action (Fig. 2) (FitzGerald i Meisel, 1999; FitzGerald et al., 2004; López-Expósito et al., 2012). However, several milk-derived antihypertensive peptides may act by different mechanisms other than inhibiting ACE such as direct vasodilator effects, antioxidant activity or by interaction with opioid receptors (Martínez-Maqueda et al., 2012).

First detected peptides derived from milk proteins with a strong ACE-inhibitory activity were tripeptides Isoleucine-Proline-Proline (IPP) and Valine-Proline-Proline (VPP) (Nakamura et al., 1995; Matsuura et al., 2005; Bütikofer et al., 2007). It was found that fermented milk containing these tripeptides effectively lowers blood pressure in humans (Seppo et al. 2002, 2003; Tuomilehto et al., 2004). Since then, a large number of peptides with similar effect have been identified and are formed during gastrointestinal digestion (Gómez-Ruiz et al., 2007; Miguel et al., 2010), fermentation (Nakamura et al., 1995; Ashar et al., 2004; Fitzgerald et al., 2004) or enzymatic hydrolysis (Hernández-Ledesma et al., 2002, 2006; Miguel et al., 2007; Contreras et al., 2011; Wang et al., 2010; Corrêa et al., 2011; Hafeez et al., 2014; Pisanu et al., 2015). Hernández-Ledesma et al. (2011) reported 40 peptides which originate from fermentation and proteolysis of caseins $\left(\alpha_{\mathrm{s1}}-\mathrm{CN}\right.$, $\alpha_{\mathrm{s} 2}-\mathrm{CN}, \beta-\mathrm{CN}$, and $\left.\kappa-\mathrm{CN}\right)$ and whey proteins $(\alpha-\mathrm{La}, \beta-\mathrm{Lg})$. Furthermore, current findings established a strong correlation between formation of these peptides in fermented products and their effect of lowering blood pressure in vivo (LópezExpósito, 2012).

ACE inhibitory peptides usually contain 2-20 amino acid residues, although active peptides with up to 27 amino acids have been found (Saito et al., 2000; Lignitto et al., 2010). ACE seems to prefer substrates or competitive inhibitors containing hydrophobic (aromatic or branched side chains) amino acid residues at each of the three C-terminal positions; the presence of lysine or arginine, with a positive charge on the 3-amino group also seems to contribute to the inhibitory potency (Murray and FitzGerald, 2007). For peptides that are longer than tetrapeptides the type and arrangement of the last four amino acid residues at the $\mathrm{C}$-terminal are known to determine in vitro potency against $\mathrm{ACE}$ (Aluko, 2012).

Cheeses as fermented products represent a potentially good source of peptides with ACE-inhibitory activity in vitro (Paul and van Hekken, 2010). However, the identification and characterization of these peptides in cheese is quite problematic due to a complex protein matrix of cheese and continuous degradation of newly formed peptides during proteolysis. Various types of cheese have been subjected to investigation regarding formation and stability of ACE-inhibitory peptides during processing and ripening. This includes Crescenza, Gorgonzola, Mozzarella, Camembert, Edam, Gouda, Cheddar, Roqueforti, Emmentaler, Parmesan, Parmigiano-Reggiano, Asiago, Gamalost, Norvegia, Brie, Fresco and Feta (Addeo et al., 1992; Smacchi and Gobbetti, 1998; Ryhänen et al., 2001; Pripp et al., 2006; Bütikofer et al., 2007; Lignitto et al., 2010; Pritchard et al., 2010; Bottesini et al., 2013). Summing up the results of a research conducted by López-Expósito et al. (2012), the presence of 92 different peptides with potential antihypertensive effects arising from $\alpha_{\mathrm{s} 1}-\mathrm{CN}$ and $\beta-\mathrm{CN}$ was indicated.
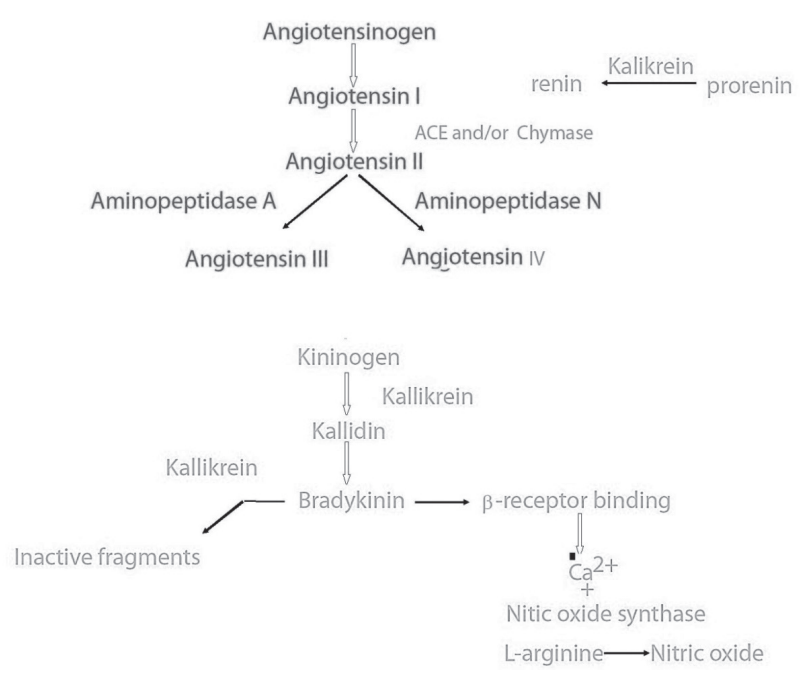

Figure 2. Renin-angiotensin and kinin-nitric oxide system (FitzGerald et al., 2004) 
Overall, according to the current knowledge, proteolysis is most probably the key stage of peptides with ACE-inhibitor activity formation. These peptides originate from starter- and non-starter lactic acid bacteria activity, although rennet enzymes showed also a potential for formation of ACE-inhibitors (Smacchi and Gobbetti, 1998). In addition, inhibiting activity registered in these cheeses depends on protein content in cheese, type of cheese and time and conditions of ripening (Pripp et al., 2006). Ong et al. (2007) demonstrated that ACEinhibitor activity of water extract of Cheddar cheese inoculated with some strains of $L b$. casei increases continuously during 24 weeks of ripening and then remains constant until the end of ripening. On the contrary, peptides with ACE-inhibitor activity detected in Parmesan after 6 months of ripening were not detected after 15 months of ripening (Addeo et al., 1992). Similarly, Gomez-Ruiz et al. (2007) detected five peptides (DKIHPF, VRYL, LPQNILP, VPSERYL, KKYNVPQL) with ACE-inhibitor activity in Manchego cheese, which was confirmed on experimental rats (Miguel et al., 2010). Their concentration varied depending on the production process and ripening duration. The level of these peptides was low after the first four months of ripening and then it had intensively grown and reached a maximum at eight months. The content of inhibitory peptides in Gouda cheese riched a maximum after six months of ripening and then significantly decreased (Meisel et al., 1997). Even though such results suggested that the degree of proteolysis significantly affected the level of activity of peptides with inhibitory activity, some literature data suggested that the nature of formed peptides also affected the ACE-inhibitory activity. Comparing ACE-inhibitory activity of different types of cheeses, Pripp et al. (2006) observed that an alcoholic extract of Kesam cheese, which is a quark type cheese, characterized by a low degree of proteolysis had a higher inhibitor activity comparing to other cheeses.

The above studies clearly showed that key factors of levels of ACE-inhibitory peptides are type of cheese, character of proteolysis, as well as the nature of the formed peptides. The process of proteolysis of white cheeses in brine was somewhat different in comparison to other types such as Gouda-type or pasta filata cheeses, why the stability of bioactive peptides was different (Fox et al., 2000).
Those differences most probably originated from white cheese ripening at high salt concentrations and mass transfer between the cheese and the brine (Hayaloglu et al., 2002) which may affect the level of bioactive peptides. Also, there is a great influence of non-starter autochthonous bacteria to these differences (Sieber et al., 2010).

Although the process of proteolysis of different types of white cheese in brine is well known (Hayaloglu et al., 2008; Alichanidis and Polychroniadou, 2008; Barać et al., 2006), ACEinhibitory activity of peptides formed during ripening is still not sufficiently characterized. Both, starter and non-starter cultures, contribute to the ACE-inhibitory activity of these cheeses (Pripp et al, 2006; Korhonen, 2009). The major part of non-starter bacteria in white brined cheeses are lactobacilli which are responsible for proteolysis and thus for the formation of ACE-inhibitory peptides as well (Sieber et al., 2010). Sahingil et al. (2014) investigated the effect of adjunct lactobacilli ( $L b$. helveticus or $L b$. casei) addition and ripening temperature $\left(6\right.$ or $\left.12{ }^{\circ} \mathrm{C}\right)$ on proteolysis and ACE-I inhibitory capacity of white brined cheese during 120 days of ripening with 30-day intervals. Their results indicated that the use of adjunct culture of $L b$. helveticus resulted in faster development of proteolysis in white brined cheese. Similarly, increasing the ripening temperature from $6{ }^{\circ} \mathrm{C}$ to $12{ }^{\circ} \mathrm{C}$ led to a faster development of proteolysis as well as production of ACE-I inhibitory peptides. Dimitrov et al. (2015) investigated the ACE-inhibitory activity of Bulgarian white cheese produced with different starter cultures. The results indicated that cheeses produced with the addition of strain L. helveticus $A 1$ had ACE-inhibitor activity, which was mainly the result of tetrapeptide Ala-Leu-Pro-Met. Erkaya and Şengul (2015) correlated the change of proteolytic parameters and ACE-inhibitor activity in vitro of water-soluble protein extracts of white cheeses made using probiotic adjunct cultures (Bifidobacterium bifidum DSMZ 20456 and Lactobacillus acidophilus DSMZ 20079). They showed that ACE-inhibitor activity of water-soluble extracts of cheeses increased throughout the ripening (IC50 values $82.78-140.99 \mu \mathrm{g} / \mathrm{mL}$ ) and that the changes were positively correlated with peptide concentration of water-soluble extracts. 
In Serbia a wide range of traditional white cheeses in brine, such as Sjenica cheese, Homolje cheese, Zlatar cheese, Zlatibor cheese and other is produced. The process of proteolysis of these cheeses is very well characterized (Maćej et al., 2004; Jovanović et al., 2004a,b; Barać et al., 2006; Radulović et al., 2011). However, there is no data related to the potential ACE-inhibitory activity of peptides formed during the ripening period. Given the huge impact of specific autochthonous microflora and quite powerful proteolytic processes, it could be assumed that these cheeses represent good source of ACE-inhibitors. Therefore, further studies should concentrate on the characterization of ACE-inhibitory peptides and their stability against digestive enzymes. Also technological factors affecting the stability of bioactive peptides in brined-type cheeses during ripening should be investigated in detail.

\section{Antioxidant peptides of white cheese in brine}

Oxidative metabolism is essential for survival of cells. A side effect of this dependence is production of free radicals and other reactive oxygen species that cause oxidative changes. Free radicals and reactive oxygen species are involved in the initiation or progress of several degenerative diseases including cancer, atherosclerosis, Alzheimer's, Parkinson's and diabetes (Aluko, 2012). Therefore, a control of oxidative stress seems to be one of the crucial steps in slowing down the progress of these diseases or preventing their complications. Besides, other well known natural food compounds such as vitamin C, polyphenols, flavonoids and carotenoids, peptides released from different sources of animal and plant origin have been recognized as antioxidants.

Mechanism of antioxidant activity of peptides and proteins is not yet quite clear. It is discussed in the literature whether the antioxidant effect evolves from single amino acid in protein sequence or if the effect is a result of interactions between multiple amino acid side chains, although most researchers agree upon the latter (Elias et al., 2008). Generally, proteins have many reactive sites that are susceptible to oxidative modification. Antioxidant property of proteins is related first to their amino acid composition. Amino acids can act as antioxidants mainly either by reducing action of their sulfhydryl groups (cysteine and methionine) or proton donation of aromatic residues to electron deficient radicals (tryptophan, tyrosine and phenylalanine). Imidazole-containing side chain of histidine is susceptible to oxidative changes, but the fact is that all of 20 biologically derived amino acids are potentially susceptible to oxidation too (Elias et al., 2008). Furthermore, correct positioning of amino acids in the protein sequence plays an important role in the antioxidant activity of proteins (Yates et al., 2010). In addition, the intramolecular transfer of radicals from one amino acid residue to another is largely dependent on the physical structure of proteins, as well as, its molecular weight. Antioxidant activity of proteins may be at least partially attributable to the lower reactivity of protein radicals, if those radicals are transferred to the interior of a complex protein where they are unable to physically interact with lipids (Østdal et al., 2002). Antioxidative properties of proteins are also related to their hydrophobicity, as well as the ability of protein to chelate and store or transport catalytically active metals that are important prooxidants in food lipids (Diaz et al., 2003; Farvin et al., 2010). Also, antioxidant enzymes such as superoxide dismutase and peroxidase, can inhibit lipid oxidation by catalyzing the conversion of superoxide anion to hydrogen peroxide and the conversion of hydrogen peroxide to water, respectively (Valko et al., 2007). Besides, the selectivity of radical attacks on amino acid side chains and physical location the radical generation can be related to the energy of oxidation (Pates et al., 2011). Finally, heating proteins in the presence of sugars can form brown polymers called melanoidins or Maillard reaction products that act as antioxidants (Žilić et al., 2012).

According to the current knowledge, antioxidant proteins and peptides partially originate from milk itself, but most of them are formed during cheese processing. Intact caseins were shown to possess antioxidant activity (Power et al., 2013). The proposed mechanism of antioxidant activity of caseins is the quenching of free radicals by the oxidation of amino acids in caseins. Parella et al. (2012) recognized mild heat treatment of milk as a stage of cheese processing during which antioxidant peptides could be released. However, cheese ripening and proteolysis are the most complex process that occur 
during ripening and are identified as the major stages of antioxidant formation. Antioxidant peptides are mostly derived from caseins due to action of peptidases released from both, starter and non-starter LAB (Pattom and Hongsprabhas, 2013; AbadiaGarcia et al., 2013; Kumar et al., 2013; Mushtaq et al., 2015, 2016), residual rennet enzymes and indigenous milk enzymes such as plasmin (Pihlanto, 2011). The level of their formation depends on ripening conditions and ripening stage (Gupta et al., 2009). Besides caseins, whey proteins and their proteolytic products also exert antioxidant activity (Zulueta et al., 2009; Hernandez-Lendesma et al. 2011; Power et al., 2013; Çekiç et al., 2015).

Although there is a large number of data about the antioxidant milk protein peptides obtained by enzymatic hydrolysis or gastrointestinal casein digestion (Diaz et al., 2003; Diaz and Decker, 2004; López-Expósito et al., 2007; Hafeez et al., 2014) and whey proteins (Hernández-Ledesma et al., 2005, 2007, 2011; Corrêa et al., 2011), until recently Cheddar was the only cheese variety which has been screened for antioxidant activity. Gupta et al. (2009) evaluated the antioxidant properties of water-soluble extracts of Cheddar cheeses prepared with Lactobacillus casei ssp. casei 300, Lactobacillus paracasei ssp. paracasei 22 and without adjunct cultures. They showed that antioxidant activity of the water-soluble extracts was dependent on the ripening period. They observed a gradual increase of the antioxidant activity up to 4 months of ripening, after which the antioxidant activity decreased and retained similar values from the seventh to the ninth month of ripening. In another study, the same authors (Gupta et al., 2010) identified two peptides responsible for the antioxidant activities of water-soluble extracts; one originated from the bovine $\beta$-CN (VKEAMAPK) and the other one originated from bovine $\alpha_{\mathrm{s1}}-\mathrm{CN}(\mathrm{f}(80-90))$. Furthermore, Pritchard et al. (2010) have evaluated the inhibition of DPPH radicals by water-soluble extracts of three different Australian Cheddar cheeses. They found a moderate antioxidant activity in those fractions containing peptides with a molecular weight greater than $10 \mathrm{kDa}$, although peptides were not identified. Researching relation between proteolysis of cheeses produced from raw and pasteurized sheep milk and bioactivity, Pisanu et al. (2015) detected 187 bioactive peptides in cheeses derived from $\alpha_{\mathrm{s} 1}-\mathrm{CN}, \beta-\mathrm{CN}$ and $\alpha_{\mathrm{s} 2}-\mathrm{CN} .9$ of the detected peptides manifested a strong antioxidant activity, and were a product of $\beta$-CN proteolysis, more precisely they originated from the fragment $f 207-221$ (QEPVLGPVRGPFPIL). Meira et al. (2012) discussed the antioxidant activity of water-soluble extracts from three Brazilian cheeses (Feta-type, Roqueforttype and Pecorino-type cheese) and two Uruguayan cheeses (Pecorino Sardo-type and Cerrilano-type) and showed that type of cheese substantially determined the content and antioxidant activity of water-soluble extracts. Accordingly, the Roqueforttype cheese had the highest content and the highest antioxidant capacity. Timón et al. (2014) examined the influence of the rennet type on the formation of radical scavering peptides smaller than $3 \mathrm{kDa}$ in Burgos, the Spanish cheese type, which is consumed fresh or after a short ripening period (up to 30 days). They used three different rennets: animal rennet (Chymosin $95 \%$ and $5 \%$ of bovine pepsin), rennet of plant origin (Cynara cardunculus) and microbial rennet (Mucor miehei). Considering the obtained results, plant and microbial rennets produced peptides with more intensive radical scavering activity than animal rennet. In addition, fractions of these cheeses contained previously unidentified peptide derived from $\alpha_{\mathrm{sl}}$-CN (f180-199), while cheeses produced with animal rennet contained this peptide in very small quantities. That peptide was derived from the C-terminal part of $\alpha_{s 1}-\mathrm{CN}$ and its molecular weight was 2217 Da. Bottesini et al. (2013) examined antioxidant capacity of water-soluble extract of Parmigiano-Reggiano cheese, before and after in vitro digestion. They noticed that carriers of antioxidant capacity in water-soluble extracts were free amino acids and to a much lesser extent, small peptides. According to these authors, this was the reason for the absence of changes in antioxidant capacity of cheese extracts after in vitro digestion.

To the authors' knowledge, there are only few published researches in which antioxidant potential of peptides of white cheese in brine was investigated. These studies were related to the antioxidant properties of white brined cheese water extracts without closer characterization of peptides responsible for the antioxidant properties. Erkaya and Şengul (2015) examined the effect of probiotic cultures addition (Bifidobacterium bifidum DSMZ 20456 and Lactobacillus acidophilus DSMZ 20079) 
and the packaging method on the change of watersoluble extract antioxidant properties. They showed that the antioxidant properties of white cheese increased with ripening and achieved a maximum after 60 days, but also that from this point more favorable ripening was in vacuum packaging. Furthermore, in terms of antioxidant capacity, use of the Lactobacillus acidophilus DSMZ 20079 strain proved to be more favorable. Gandhi and Shah (2016) investigated the effect of salt reduction on bioactive characteristics of water extract of Akawi - white cheese usually produced in Lebanon, Jordan and Palestine. They noticed that this parameter did not significantly affect antioxidant properties of Akawi cheese extracts and there was no correlation between proteolysis parameters and antioxidant capacity. However, Ghandi and Shah (2016) also monitored the changes in those parameters during 30 days of ripening. On the contrary, considering the possibility of applying the procedure of overheating $\left(90^{\circ} \mathrm{C}\right.$, $10 \mathrm{~min}$ ) of milk of different origin (cow and goat milk) in combination with traditional production process of Serbian white cheese (without the addition of starter cultures), Barać et al. (2016 a,b) noticed by PCA analysis a strong relationship between the parameters of proteolysis and the water-soluble extract antioxidant capacity. Also there was a strong relationship between proteolysis and the antioxidant capacity of water-insoluble fraction (Fig. 3). Namely, considering antioxidant properties of caseins and whey proteins that are incorporated into the protein matrix of cheese, Barać et al. (2016) assumed that the water-insoluble fraction possesses an antioxidant potential as well. According to the results of these studies both protein fractions had a great antioxidant capacity, which was in range of capacities of plant protein products (Žilić et al., 2012) that are characterized as functional.

\section{Other forms of bioactivity of white brined cheese peptides}

In the available literature there are only few studies about other forms of bioactivity of white brined cheese peptides. They refer to antimicrobial, antitumor and calcium-binding properties of peptides in water extract of white brined cheese. Dimitrov et al. (2015) investigated the effect of different strains of lactic acid bacteria on the calcium-binding activity of water-soluble extract of the Bulgarian white cheese. They noticed that peptides in cheese prepared with strain L. casei C3 had the best calcium-binding activity. As a main contributor to calcium binding-activity they identified the peptide SpLSpSpSpE (fraction 15-20 of $\beta$-casein). Without going into the nature of the action, Gandhi and Shah (2016) registered a slowdown in the growth of colon tumor cells using water extracts of Akawi cheese peptides. Although the number of antimicrobial peptides derived from casein and whey proteins generated by various commercial proteases and bacteria to the pure solutions of these proteins or to the fermented product were identified (Benkerroum, 2010; Hafeez et al., 2014), we did not find data relating to their presence in white

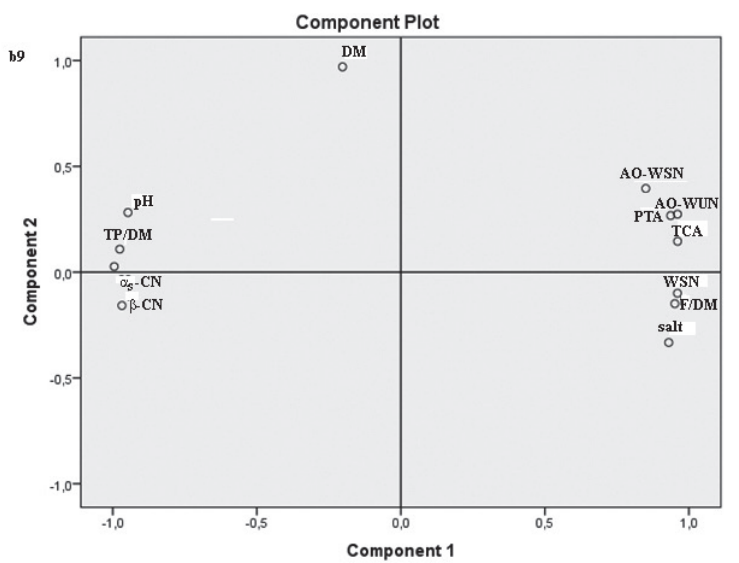

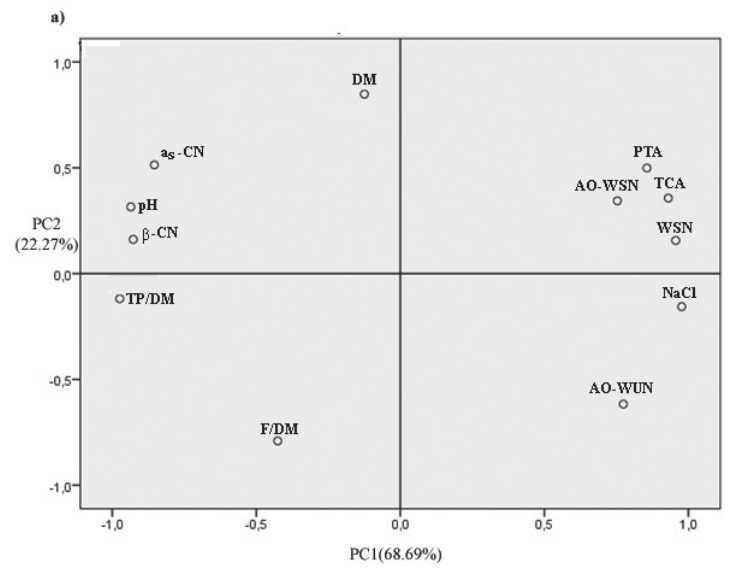

Figure 3. Principal component analysis (PCA) of white cheese prepared from overheated goat (a) and cow (b) milk PC1 x PC2 (Barac et al., 2016 a, b). 
cheeses. So far, investigations of white cheese antimicrobial properties were based on isolation of autochthonous microflora and examination of their ability to synthesize antimicrobial peptides such as bacteriocins. Bacteriocins are ribosomally synthesized, extracellularly released bioactive peptides or peptide complexes (consists of 20-60 amino acid residues) with bactericidal or bacteriostatic effect on other species (Cotter et al., 2005; Andrade et al., 2008). They are synthesized by different groups of bacteria, including some strains of LAB (Bernardeau et al., 2008). Favaro et al. (2014) investigated the potential of forming bacteriocins by a non-starter culture from the Bulgarian home-made white goat cheese in brine. Accordingly, four strains of autochthonous bacteria were identified as potential biopreservative cultures in cheese/milk fermentations.

\section{Future trends}

The potential health benefits of bioactive cheese peptides have been a subject of growing commercial interest in the context of health-promoting functional foods. However, this review clearly shows that bioactive potential of white brined cheeses is still insufficiently explored. Despite the lack of information on particular bioactivity of peptides that are formed during production of white brined cheese, it could be seen that their functionality considerably differs from other types of cheeses. Such findings are most probably related to the specifics of ripening, absence of application of starter cultures in production of traditional types of white cheese and great influence of autochthonous microflora. Future research should be directed towards a more detailed characterization of peptides responsible for particular bioactivity, especially in traditional types and defining factors that affect the optimal formation during cheese production, taking into account the relationship between bioactivity and sensory characteristics. As most of the data present in the literature relate to peptides from cow milk cheeses, further investigations should be focused on a detailed examination of bioactivity of peptides originating from sheep and goat milk cheeses. Carriers of bioactivity are usually low molecular weight peptides (di-, tri- and tetrapeptides) which are often carriers of bitter taste. Therefore it is necessary to define the optimal ratio of their content and the bitterness of cheese. Furthermore, future research should also address the production of nutritionally valuable white cheeses in which whey proteins would be incorporated to a greater extent by applying appropriate technological procedures, which would also contribute to considerably higher bioactivity of white cheese. In this context, specific research should be directed to the implementation of commercial proteolytic enzymes in certain stages of white cheese production, which would affect the degree of formation of bioactive peptides, and therefore the functionality of white cheeses.

\section{Acknowledgement}

This work was supported by the Serbian Ministry of Education, Science and Technological Development.

\section{Bijeli sirevi u salamuri kao potencijalni izvor bioaktivnih peptida}

\section{Sažetak}

Sirevi kao i drugi fermentirani proizvodi na bazi mlijeka, osim izražene nutritivne vrijednosti, predstavljaju i dobar izvor biološki aktivnih proteina i peptida. Bioaktivni peptidi sira najvećim dijelom nastaju prilikom proizvodnje sira, a posebno tijekom zrenja, kao jedne od najznačajnijih faza u procesu proizvodnje. Kako se proces zrenja različitih tipova sira bitno razlikuje, može se pretpostaviti da se i njihova bioaktivnost bitno razlikuje. Bijeli sirevi u salamuri specifični su za podneblje Jugoistočne Europe, a odlikuju se dosta intenzivnim procesima proteolize te mogu biti zanimljivi kao proizvodi s povoljnim funkcionalnim karakteristikama. U tom smislu ovaj tip sira još uvijek nije dovoljno okarakteriziran. Ovaj rad predstavlja pregled dosadašnjih saznanja o bioaktivnim peptidima bijelih sireva u salamuri.

Ključne riječi: bioaktivni peptidi, bijeli sir u salamuri, proteoliza 


\section{References}

1. Abadia-Garcia, L., Cardador, A., Martin del Campo, S.T., Arvizu, S.M., Castano- Tostado, E., RegaladoGonzalez, C. (2013): Influence of probiotic strains added to cottage cheese on generation of potentially antioxidant peptides, antilisterial activity, and survival of probiotic microorganisms in simulated gastrointestinal conditions. International Dairy Journal 33, 191-197. https://doi.org/10.1016/j.idairyj.2013.04.005

2. Addeo, F., Chianese, L., Salzano, A., Sacchi, R., Cappuccio, U., Ferranti, P. Malirni, A. (1992): Characterization of the $12 \%$ tricholoroacetic acid insoluble oligopeptides of Parmigiano- Reggiano cheese. Journal of Dairy Research 59, 401-411. https://doi.org/10.1017/S0022029900030673

3. Alichanidis, E., Polychroniadou, A. (2008): Characteristics of major traditional regional cheese varieties of East-Mediterranean countries: a review. Dairy Science and Technology 88, 495-510. https://doi.org/10.1051/dst:2008023

4. Aluko, R. (2012): Functional Foods and Nutraceuticals, Springer, New York, 1-149. https://doi.org/10.1007/978-1-4614-3480-1

5. Andrade, C.C.P., Mandelli, F., Echeverrigaray, Delamare, S.A.P. (2008): Microbial dynamics during cheese production and ripening: physicochemical and biological factors. Food 2 (2), 91-101.

6. Ashar, M.N., Chand, R. (2004): Fermented milk containing ACE-inhibitory peptides reduces blood pressure in middle aged hypertensive subjects, Milchwissenschaft 59, 363-366.

7. Barać, M., Jovanović, S., Maćej, O. (2006): Proteolytic changes during ripening of autochthonous white cheeses in brine, Autochthonous white cheeses in brine, Faculty of Agriculture, Belgrade, 65-87. ISBN 86-7834-008-8.

8. Barać, M., Smiljanić, M., Pesić, M., Stanojević, S., Jovanović, S., Maćej, O. (2013): Primary proteolysis of white brined goat cheese monitored by high molarity Tris buffer SDS- PAGE system. Mljekarstvo 63 (3), 122-131.

9. Barać, M., Smiljanić, M., Žilić, S., Pesić, M., Stanojević, S., Vasić, M., Vučić, T. (2016): Protein profiles and total antioxidant capacity of water soluble and insoluble protein fractions of white cow cheese at different stage of ripening. Mljekarstvo 66 (3), 187-197. https://doi.org/10.15567/mljekarstvo.2016.0303

10. Barac, M., Pesic, M., Zilic, S., Smiljanic, M., Stanojevic, S., Vasic, M., Despotovic, S., Vucic, T., Kostic, A. (2016): Protein profiles and total antioxidant capacity of watersoluble and water-insoluble fractions of white brined goat cheese at different stages of ripening. International Journal of Food Science and Technology 51 (5), 1140-1149. https://doi.org/10.1111/ijfs.13091

11. Baum, F., Fedorova, M., Ebner, J., Hoffmann, R., Pischetsrieder, M. (2013): Analysis of the endogenous peptide profile of milk: Identification of 248 mainly casein derived peptides. Journal of Proteome Research 12, 5447-5462. https://doi.org/10.1021/pr4003273
12. Benkerroum, N. (2010): Antimicrobial peptides generated from milk proteins: a survey and prospects for application in the food industry. A review. International Journal of Dairy Technology 63 (3), 320-338. https://doi.org/10.1111/j.1471-0307.2010.00584.x

13. Bernardeau, M., Vernoux J.P., Henri-Dubernet, S., Guéguen, M. (2008): Safety assessment of dairy microorganisms: The Lactobacillus genus. International Journal of Food Microbiology 126 (3), 278-285. https://doi.org/10.1016/j.ijfoodmicro.2007.08.015

14. Bottesini, C., Paolella, S., Lambertini, F., Galaverna, G., Tedeschi, T., Dossena, A., Marchelli, R., Sforza, S (2013): Antioxidant capacity of water soluble extracts from Parmigiano-Reggiano cheese. International Journal of Food Sciences and Nutrition 64 (8), 953-958. https://doi.org/10.3109/09637486.2013.821696

15. Bütikofer, U., Meyer, J., Sieber, R., Wechsler, D. (2007): Quantification of the angiotensin-converting enzyme-inhibiting tripeptides Val-ProPro and Ile-Pro-Pro in hard, semi-hard and soft cheeses. International Dairy Journal 17, 968-975. https://doi.org/10.1016/j.idairyj.2006.11.003

16. Çekiç, S.D., Demir, A., Başkan, K.S., Tütem, E., Apak, R. (2015): Determination of total antioxidant capacity of milk by CUPRAC and ABTS methods with separate characterisation of milk protein fractions. Journal of Dairy Research 82, 177-184. https://doi.org/10.1017/S0022029915000114

17. Chevalier, F.O., Hirtz, C., Sommerer, N., Kelly, A.L. (2009): Use of reducing/nonreducing two-dimensional electrophoresis for the study of disulfide-mediated interactions between proteins in raw and heated bovine milk. Journal of Agricultural and Food Chemistry 57, 5948-5955. https://doi.org/10.1021/jf900518n

18. Contreras, María del Mar, Hernández-Ledesma, B., Martín-Álvarez, L., Pedro J., Recio, I. (2011): Production of antioxidant hydrolyzates from a whey protein concentrate with thermolysin: Optimization by response surface methodology. LWT - Food Science and Technology 44 (1), 9-15. https://doi.org/10.1016/j.lwt.2010.06.017

19. Corrêa, A.P.F., Daroit, D.J., Coelho, J., Meira, S.M., Lopes, F.C., Segalin, J., Risso, P.H., Brandelli, A. (2011): Antioxidant, antihypertensive and antimicrobial properties of ovine milk caseinate hydrolyzed with a microbial protease. Journal of Agricultural and Food Chemistry 91, 2247-2254. https://doi.org/10.1002/jsfa.4446

20. Cotter, P.D., Hill, C., Ross, R.P. (2005): Bacteriocins: developing innate immunity for food. Nature Reviews Microbiology 3, 777-788. https://doi.org/10.1038/nrmicrol273

21. De Simone, C., Picariello, G., Mamone, G., Stiuso, P., Dicitore, A., Vanacore, D., Chianese, L., Addeo, F., Ferranti, P. (2009): Characterization and cytomodulatory properties of peptides from Mozzarella di Bufala Campana cheese whey. Journal of Peptide Science 15, 251-258. https://doi.org/10.1002/psc.1093 
22. Diaz, M., Dunn, C.M., McClements, D.J., Decker, E.A. (2003): Use of caseinophosphopeptides as natural antioxidants in oil-in-water emulsions. Journal of Agricultural and Food Chemistry 51, 2365-2370. https://doi.org/10.1021/jf0259841

23. Diaz, M., Decker, E.A. (2004): Antioxidant mechanisms of caseinophosphopeptides and casein hydrolysates and their application in ground beef. Journal of Agricultural and Food Chemistry 52, 8208-8213. https://doi.org/10.1021/jf048869e

24. Dimitrov, Z., Chorbadjiyska, E., Gotova, I., Pashova, K., Ilieva, S. (2015): Selected adjunct cultures remarkably increase the content of bioactive peptides in Bulgarian white brined cheese. Biotechnology \& Biotechnological Equipment 29 (1), 78-83. https://doi.org/10.1080/13102818.2014.969918

25. Dozet, N. (2004): Travnik-Vlasic cheese - cheeses in brine, Faculty of Agriculture, University of Eastern Sarajevo 49-78.

26. Elias, R.J., Kellerby, S.S., Decker, E.A. (2008): Antioxidant activity of proteins and peptides. Critical Reviews in Food Science and Nutrition 48, 430-441. https://doi.org/10.1080/10408390701425615

27. Erkaya, T., Şengul, M. (2015): Bioactivity of water soluble extracts and some characteristics of white cheese during the ripening period as effected by packaging type and probiotic adjunct cultures. Journal of Dairy Research 82 (1), 47-55. https://doi.org/10.1017/S0022029914000703

28. Farvin, K.H.S., Baron, C.P., Nielsen, N.S., Otte, J., Jacobsen, C. (2010): Antioxidant ac-tivity of yoghurt peptides: Part 2-Characterisation of peptide fractions. Food Chemistry 123, 1090-1097. https://doi.org/10.1016/j.foodchem.2010.05.029

29. Favaro, L., Basaglia, M., Casella, S., Hue, I., Dousset, X., M., Franco, B.D.G., Todorov, S. D. (2014): Bacteriocinogenic potential and safety evaluation of non-starter Enterococcus faecium strains isolated from home made white brine cheese. Food Microbiology 38, 228-239. https://doi.org/10.1016/j.fm.2013.09.008

30. FitzGerald, R.J., Meisel, H. (1999): Lactokinins: whey protein-derived ACE inhibitory peptides. Nahrung 43, 165-167.

https://doi.org/10.1002/(SICI)1521-3803 (19990601)43:3<165::AID-FOOD165>3.0.CO;2-2

31. FitzGerald, R.J., Murray, BA., Daniel, J. (2004): Walsh hypotensive peptides from milk proteins. Journal of $\mathrm{Nu}$ trition 134 (4), 980S-988S.

32. Fox, P.F., Guinee, T.P., Cogan, T.M., McSweeney, P.L.H. (2000): Fundamentals of cheese science, pp. 585. Gaithershurg, Maryland, An Aspen Publication.

33. Fox, P.F., Law, J., McSweeny, P.L.H., Wallace, J. (1993). Cheese: chemistry, physics and microbiology. Chapman \& Hall, London, UK. 389-438. https://doi.org/10.1007/978-1-4615-2650-6
34. Gagnaire, V., Carpino, S., Pediliggieri, C., Jardin, J., Lortal, S., Licitra, G. (2011): Uncommonly thorough hydrolysis of peptides during ripening of Ragusano cheese revealed by tandem mass spectrometry. Journal of Agricultural and Food Chemistry 59, 12443-12452. https://doi.org/10.1021/jf2027268

35. Gandhi, A., Shah, N. P. (2016): Salt reduction in a model high-salt Akawi cheese: Effects on bacterial activity, $\mathrm{pH}$, moisture, potential bioactive peptides, amino acids, and growth of human colon cells. Journal of Food Science 81 (4), H991-H1000. https://doi.org/10.1111/1750-3841.13260

36. Gómez-Ruiz J.A., Ramos, M., Recio, I. (2007): Identification of novel angiotensin converting enzyme-inhibitory peptides from ovine milk proteins by CE-MS and chromatographic techniques. Electrophoresis 28, 4202-4208. https://doi.org/10.1002/elps.200700324

37. Gupta, A., Mann, B., Kumar, R., Sangwan, R. (2009): Antioxidant activity of Cheddar cheeses at different stages of ripening. International Journal of Dairy Technology 62, 339-347. https://doi.org/10.1111/j.1471-0307.2009.00509.x

38. Gupta, A., Mann, B., Kumar, R., Sangwan, R.B. (2010): Identification of antioxidant peptides in Cheddar cheese made with adjunct culture Lactobacillus casei ssp casei 300. Milchwissenschaft 65, 396-399.

39. Hafeez, Z., Cakir-Kiefer, C., Roux, E. Perrin, C., Miclo, L., Dary-Mourot, A. (2014): Strategies of producing bioactive peptides from milk proteins to functionalize fermented milk products. Food Research International 63, 71-80. https://doi.org/10.1016/j.foodres.2014.06.002

40. Hayaloglu, A.A., Guven, M., Fox, P.F. (2002): Microbiological, biochemical and technological properties of Turkish White cheese "Beyaz Peynir". International Dairy Journal 12, 635-648. https://doi.org/10.1016/S0958-6946(02)00055-9

41. Hayaloglu, A.A., Ozer, B.H., Fox, P.F. (2008). Cheeses of Turkey: 2. Varieties ripened under brine. Dairy Science and Technology 88, 225-244. https://doi.org/10.1051/dst:2007014

42. Hernández-Ledesma, B., del Mar Contreras, M., Recio, I. (2011): Antihypertensive peptides: Production, bioavailability and incorporation into foods Blanca. Advances in Colloid and Interface Science 165, 23-35. https://doi.org/10.1016/j.cis.2010.11.001

43. Hernandez-Ledesma, B., Davalos, A., Bartolome, B., Amigo, L. (2005): Preparation of antioxidant enzymatic hydrolysates from alpha-lactalbumin and beta-lactoglobulin. Identification of active peptides by HPLC-MS/MS. Journal of Agricultural and Food Chemistry 53, 588-593. https://doi.org/10.1021/jf048626m

44. Hernández-Ledesma, B., Miguel, M., Amigo, L., Aleixandre, M.A., Recio, I. (2007): Effect of simulated gastrointestinal digestion on the antihypertensive properties of synthetic beta-lactoglobulin peptide sequences. Journal of Dairy Research 74, 336-343. https://doi.org/10.1017/S0022029907002609 
45. Hernández-Ledesma, B., Ramos, M., Recio, I., Amigo, L. (2006): Effect of $\beta$-lactoglobulin hydrolysis with thermolysin under denaturing temperatures on the release of bioactive peptides. Journal of Chromatography A, 1116-1131. https://doi.org/10.1016/j.chroma.2006.03.006

46. Hernández-Ledesma, B., Recio, I., Ramos, M., Amigo, L. (2002): Preparation of ovine and caprine $\beta$-lactoglobulin hydrolysates with ACE-inhibitory activity. Identification of active peptides from caprine $\beta$-lactoglobulin hydrolysed with thermolysin. International Dairy Journal 12, 805-813. https://doi.org/10.1016/S0958-6946(02)00080-8

47. Jovanovic, S., Barac, M, Macej, O. (2004a): Characteristics of autohtonous production of Homolje white cheese in brine. Biotechnology in Animal Husbandry 20, $157-$ 165.

48. Jovanović, S., Macej, O., Barac, M. (2004b): Characteristics of autochthonous white cheese production in the area of Sjenica-Pester plateau. Biotechnology in Animal Husbandry 20, 131-140. https://doi.org/10.2298/BAH0402131 J

49. Jovanović, S., Barać, M., Maćej, O., Denin Đurđević, J. (2005a): PAGE analysis of milk proteins altered by high thermal treatment. Acta Alimentaria 34 (2), 105-112. https://doi.org/10.1556/AAlim.34.2005.2.2

50. Jovanović, S., Barać M., Maćej O. (2005b): Whey proteins-Properties and Possibility of Application. Mljekarstvo $55,215-233$.

51. Kitts, D.D., Weiler K. (2003): Bioactive proteins and peptides from food sources. Applications of bioprocesses used in isolation and recovery. Current Pharmacutical Design 9 (16), 1309-1323. https://doi.org/10.2174/1381612033454883

52. Korhonen H, Pihlanto A. (2006): Review: bioactive peptides: production and functionality. International Dairy Journal 16, 945-960. https://doi.org/10.1016/j.idairyj.2005.10.012

53. Korhonen, H., Pihlanto-Leppala, A., Rantamaki, P., Tupasela, T. (1998): Impact of processing on bioactive proteins and peptides. Trends in Food Science and Technology 9, 307-319. https://doi.org/10.1016/S0924-2244(98)00054-5

54. Korhonen, H. (2009) Milk derived bioactive peptides: From science to application. Journal of functional foods 1 (2) 177-178. https://doi.org/10.1016/j.jff.2009.01.007

55. Korhonen, H., Marnila, P. (2013): Milk bioactive proteins and peptides, in Milk and dairy products in human nutrition and helth, Park, Y. and Haienlain, G. (eds), John Willey and Sons, UK, 148-188. https://doi.org/10.1002/9781118534168.ch8

56. Kumar, S., Teotia, U.V.S., Sanghi, A. (2013): Antioxidative property of cow milk caseinates hydrolyzed with different proteases. International Journal of Pharmacy and Pharmaceutical Sciences 5, 418-422.
57. Lignitto, L, Cavatorta, V, Balzan, S., Gabai, G., Galaverna, G., Novelli, E, Sforza, S., Segato, S. (2010): Angiotensinconverting enzyme-inhibitory activity of water-soluble extracts of Asiago d allevo cheese. International Dairy Journal 20, 11-17. https://doi.org/10.1016/j.idairyj.2009.07.001

58. Lisak-Jakopović, K., Barukčić, I., Božanić, R. (2016): Physiological significance, structure and isolation of $\alpha$-lactalbumin. Mljekarstvo 66 (1), 3-11. http://dx.doi.org/10.15567/mljekarstvo.2016.0101

59. López-Expósito, I., Amigo, L., Recio, I. (2012): A mini-review on health and nutritional aspects of cheese with a focus on bioactive peptides. Dairy Science and Technology 92, 419-438. https://doi.org/10.1007/s13594-012-0066-5

60. López-Expósito, I., Quirós, A., Amigo, L., Recio, I. (2007): Casein hydrolysates as a source of antimicrobial, antioxidant and antihypertensive peptides. Le Lait 87, 241-249. https://doi.org/10.1051/lait:2007019

61. Maćej, O., Jovanović, S, Barać, M. (2004): The effect of milk type on quality of Sjenica cheese and Sjenica type cheese made by authtonous technology. Biotechnology in Animal Husbandry 20, 109-118. https://doi.org/10.2298/BAH0402109M

62. Maćej, O., Jovanović, S., Barać, M. (2007): Milk proteins (book in Serbian), Faculty of Agriculture, Belgrade, 223-256.

63. Martínez-Maqueda, D., Miralles, B., Recio, I., Hernández-Ledesma, B. (2012): Antihypertensive peptides from food proteins: a review. Food \& Function 3, 350-361. https://doi.org/10.1039/c2fol0192k

64. Matsuura, K., Mizuno, S., Nishimura, S., Gotou, T., Yamamoto, N. (2005): Quantitative analysis of the antihypertensive peptides Val-Pro-Pro and Ile-Pro-Pro in casein hydrolyzate using an Aspergillus oryzae protease: an LCMS method. Milchwissenschaft 60, 24-27.

65. Meira, S. M. M., Daroit, D.J., Helfer, V.E., Corrêa, A.P.F., Segalin, J., Carro, S., Brandelli, A. (2012): Bioactive peptides in water-soluble extracts of ovine cheeses from Southern Brazil and Uruguay. Food Research International 48, 322-329. https://doi.org/10.1016/j.foodres.2012.05.009

66. Meisel, H., Goepfert, A., Gunther, S. (1997): ACEinhibitory activities in milk products. Milchwissenschaft 52, 307-311.

67. Miguel, M., Gómez-Ruiz J.A., Recio, I., Aleixandre, A. (2010): Changes in arterial blood pressure after single oral administration of milk-casein-derived peptides in spontaneously hypertensive rats. Molecular Nutrition and Food Research 54, 1422-1426. https://doi.org/10.1002/mnfr.200900448

68. Miguel, M., Manso, M.A., López-Fandiño, R., Alonso, M.J., Salaices, M. (2007): Vascular effects and antihypertensive properties of kappa-casein macropeptide. International Dairy Journal 17, 1473-1480. https://doi.org/10.1016/j.idairyj.2007.04.009 
69. Murray, B.A., FitzGerald, R.J. (2007): Angiotensin converting enzyme inhibitory peptides derived from food proteins: Biochemistry, bioactivity and production. Current Pharmaceutical Design 13, 773-791. https://doi.org/10.2174/138161207780363068

70. Mushtaq, M., Gani, A., Shetty, P. H., Masoodi, F. A., Ahmad, M. (2015): Himalayan cheese (Kalari/kradi): effect of different storage temperatures on its physicochemical, microbiological and antioxidant properties. LWT-Food Science and Technology 63 (2), 837-845. https://doi.org/10.1016/j.lwt.2015.04.054

71. Mushtaq, M., Gani, A., Masoodi, F.A., Ahmad M. (2016): Himalayan cheese (Kalari/Kradi)- Effect of different probiotic strainson oxidative stability, microbiological, sensory and nutraceutical properties during storage. LWT - Food Science and Technology 67, 74-81. https://doi.org/10.1016/j.lwt.2015.11.039

72. Nagpal, R., Behare, P., Rana, R., Kumar, A., Kumar, M., Arora, S., Morotta, F., Jain, S., Yadav, H. (2011): Bioactive peptides derived from milk proteins and their health beneficial potentials: an update. Food and Function 2 (1), 18-27. https://doi.org/10.1039/C0FO00016G

73. Nakamura, Y., Yamamoto, N., Sakai, K., Takano, T. (1995): Antihypertensive effect of sour milk and peptides isolated from it that are inhibitors to angiotensin I-converting enzyme. Journal of Dairy Science 78, 1253-1257. https://doi.org/10.3168/jds.S0022-0302(95)76745-5

74. Ong, L., Henriksson, A., Shah, N. (2007): Angiotensin converting enzymeinhibitory activity in Cheddar cheeses made with the addition of probiotic Lactobacillus casei sp. Le Lait 87, 149-165. https://doi.org/10.1051/lait:2007004

75. Østdal, H., Davies, M.J., Andersen, H.J. (2002): Reaction between protein radicals and other biomolecules. Free Radical Biology and Medicine 33 (2), 201-209. https://doi.org/10.1016/S0891-5849(02)00785-2

76. Otte, J., Samah. M. Shalaby, A., Zakora, M. Nielsen, M.S. (2007): Fractionation and identification of ACE-inhibitory peptides from $\alpha$-lactalbumin and $\beta$ -casein produced by thermolysin-catalysed hydrolysis. International Dairy Journal 17, 1460-1472. https://doi.org/10.1016/j.idairyj.2007.04.008

77. Parrella, A., Caterino, E., Cangiano, M., Criscuolo, E., Russo, E., Lavorgna, M., Isidori, M. (2012): Antioxidant properties of different milk fermented with lactic acid bacteria and yeast. International Journal of Food Science and Technology 47, 2493-2502. https://doi.org/10.1111/j.1365-2621.2012.03127.x

78. Pates, G.O., Guler, L., Nash, J.J., Kenttämaa, H.I. (2011): Reactivity and selectivity of charged phenyl radicals toward amino acids in a Fourier transform ion cyclotron resonance mass spectrometer. Journal of the American Chemical Society 133 (24), 9331-9342. https://doi.org/10.1021/jal 11280t

79. Pattom,S.,Hongsprabhas,P.(2013):Effectofcoagulantson antioxidant capacity of milk protein curds and their tryptic hydrolysates. Journal of Food Biochemistry 37, 203-211. https://doi.org/10.1111/j.1745-4514.2011.00625.x
80. Paul, M., van Hekken, D.L. (2010): Assessing antihypertensive activity in native and model queso fresco cheeses. Journal of Dairy Science 94, 2280-2284. https://doi.org/10.3168/jds.2010-3852

81. Pesic, M.B., Barac M.B., Stanojevic S.P., Vrvic M.V. (2015): Heat-induced casein-whey protein interactions in caprine milk: whether are similar to bovine milk? In Series: Food Engineering Series, Book: Emerging and Traditional Technologies for Safe, Healthy and Quality food, Nedovic V., Raspor P., Tumbas V. and Barbosa-Cánovas G. (Eds.). Chapter 9. https://doi.org/10.1007/978-3-319-24040-4_9

82. Pesic, M., Barac, M., Vrvic, M., Ristic, N., Macej, O., Stanojevic, S. (2011): Qualitative and quantitative analysis of bovine milk adulteration in caprine and ovine milks using native-PAGE. Food Chemistry 125 (24), 1443-1449. https://doi.org/10.1016/j.foodchem.2010.10.045

83. Pesic, M., Barac, M., Vrvic, M., Kostic, A, Macej, O., Ristic, N. (2012a): The distributions of major whey proteins in acid wheys obtained from caprine/bovine and ovine/bovine milk mixtures. International Dairy Journal 21 (10), 831-838.

84. Pesic, M.B., Barac, M.B. Stanojevic, S.P., Ristic, N.M., Macej, O.D., Vrvic, M.M. (2012b): Heat induced casein-whey protein interactions at natural $\mathrm{pH}$ of milk: A comparison between caprine and bovine milk. Small Ruminant Research 108 (1-3), 77-86. https://doi.org/10.1016/j.smallrumres.2012.06.013

85. Pesic, M.B., Barac, M.B., Stanojevic, S.P., Vrvic, M.M. (2014): Effect of $\mathrm{pH}$ on heat-induced casein-whey protein interactions: A comparison between caprine milk and bovine milk. International Dairy Journal 39 (1), 178-183. https://doi.org/10.1016/j.idairyj.2014.06.006

86. Phelan, M., Kerins, D. (2011): The potential role of milk-derived peptides in cardiovascular disease. Food and Function 2 (3-4), 153-67. https://doi.org/10.1039/clfol0017c

87. Pihlanto, A. (2011): Whey proteins and peptides: emerging properties to promote health. Nutrafoods 10, 29-42. https://doi.org/10.1007/BF03223386

88. Pisanu, S., Pagnozzi, D. Pes, M., Pirisi, A., Roggio, T., Uzzau, S., Addis, M. F. (2015): Differences in the peptide profile of raw and pasteurised ovine milk cheese and implications for its bioactive potential. International Dairy Journal 42, 26-33. https://doi.org/10.1016/j.idairyj.2014.10.007

89. Power, O., Jakeman, P., FitzGerald, R.J. (2013): Antioxidative peptides: enzymatic production, in vitro and in vivo antioxidant activity and potential applications of milk-derived antioxidative peptides. Amino Acids 44, 797-820. https://doi.org/10.1007/s00726-012-1393-9

90. Pripp, A.H., Sorensen, R., Stepaniak, L., Sorhaug, T. (2006): Relationship between proteolysis and angiotensin-I-converting enzyme inhibition in different cheeses. LWT-Food Science and Technology 39, 677-683. https://doi.org/10.1016/j.lwt.2005.03.018 
91. Pritchard, S., Phillips, M., Kailasapathy, K. (2010): Identification of bioactive peptides in commercial Cheddar cheese. Food Research International 43 (5), 1545-1548. https://doi.org/10.1016/j.foodres.2010.03.007

92. Radulović, Z., Miočinović, J., Pudja, P., Barać, M., Miloradović, Z., Paunović, D., Obradović, D. (2011): The application of autochthonous lactic acid bacteria in white brined cheese production. Mljekarstvo 61 (1), 15-25.

93. Ryhänen, E.L., Pihlanto, L.A., Pahkala, E. (2001): A new type of ripened; low-fat cheese with bioactive properties. International Dairy Journal 11, 441-447. https://doi.org/10.1016/S0958-6946(01)00079-6

94. Sahingil, D. Hayaloglu, A.A., Kirmaci, H.A., Özer, B., Simsek, O. (2014): Changes of proteolysis and angiotensin-I converting enzyme-inhibitory activity in whitebrined cheese as affected by adjunct culture and ripening temperature. Journal of Dairy Research 81, 394-402. https://doi.org/10.1017/S0022029914000326

95. Saito, T., Nakamura, T., Kitazawa, H., Kawai, Y., Itoh, T. (2000): Isolation and structural analysis of antihypertensive peptides that exist naturally in gouda cheese. Journal of Dairy Science 83, 1434-1440. https://doi.org/10.3168/jds.S0022-0302(00)75013-2

96. Sarantinopoulos, P., Kanaltzopoulos, G., Tsakalidou, E. (2002): Effect of Enterococcus faecium on microbiological, physicochemical and sensory characteristics of Greek feta cheese. International Journal of Food Microbiology 76, 93-105. https://doi.org/10.1016/S0168-1605(02)00021-1

97. Seppo, L., Kerojoki, O., Suomalainen, T., Korpela, R. (2002): The effect of a Lactobacillus helveticus LBK-16 $\mathrm{H}$ fermented milk on hypertension-a pilot study on humans. Milchwissenschaft 57, 124-127.

98. Seppo, L., Jauhianene, T., Poussa, T., Korpela, R. (2003): A fermented milk high in bioactive peptides has a blood pressure-lowering effect in hypertensive subjects. American Journal of Clinical Nutrition 77 326-330.

99. Sforza, S., Ferroni, L., Galaverna, G., Dossena, A., Marchelli, R. (2003): Extraction, semi-quantification, and fast on-line identification of oligopeptides in Grana Padano cheese by HPLC-MS. Journal of Agricultural and Food Chemistry 51 (8), 2130-2135. https://doi.org/10.1021/jf025866y

100. Sforza, S., Cavatorta, V., Lambertini, F., Galaverna, G., Dossena, A., Marchelli, R. (2012): Cheese peptidomics: a detailed study on the evolution of the oligopeptide fraction in Parmigiano-Reggiano cheese from curd to 24 months of aging. Journal of Dairy Science 95 (7), 3514-3526. https://doi.org/10.3168/jds.2011-5046

101. Sieber, R., Bütikofer, U., Egger, C., Portmann, R., Walther, B., Wechsler, D. (2010): ACE inhibitory activity and ACE-inhibiting peptides in different cheese varieties. Dairy Science and Technology 90, 47-73. https://doi.org/10.1051/dst/2009049
102. Smacchi, E., Gobbetti, M. (1998): Peptides from several Italian cheeses inhibitory to proteolytic enzymes of lactic acid bacteria, Pseudomonas fluorescens ATCC 948 and to the angiotensin-I-converting enzyme. Enzyme and Microbial Technology 22, 687-694. https://doi.org/10.1016/S0141-0229(97)00261-5

103. Smiljanić, M., Pesic, M., Stanojevic, S., Barać, M. (2014): Primary proteolysis of white brined cheese prepared from raw cow milk monitored by high-molarity Tris buffer SDS-PAGE system. Mljekarstvo 64 (2), 102-110.

104. Timón, M.L., Parra, V., Otte, J., Broncano, J., María, M., Petrón, J. (2014): Identification of radical scavenging peptides $(<3 \mathrm{kDa})$ from Burgos-type cheese. LWT - Food Science and Technology 57, 359-365. https://doi.org/10.1016/j.lwt.2014.01.020

105. Tuomilehto, J., Lindstrom, J., Hyyrynen, J., Korpela, R., Karhunen, M.-L., Mikkola, L., Jauhiainen, T., Seppo, L., Nissinen, A. (2004): Effect of ingesting sour milk fermented by Lactobacillus helveticus bacteria on blood pressure in subjects with mild hypertension. Journal of Human Hypertension 18, 795-802. https://doi.org/10.1038/sj.jhh.1001745

106. Valko, M., Leibfritz, D., Moncol, J., Cronin, M.T.D., Mazur, M., Telser, J. (2007): Free radicals and antioxidants in normal physiological functions and human disease. The International Journal of Biochemistry \& Cell Biology 39, 44-84. https://doi.org/10.1016/j.biocel.2006.07.001

107. Vasbinder, A.J., de Kruif, C.G. (2003). Caseinwhey protein interactions in heated milk: the influence of pH. International Dairy Journal 13, 669-677. https://doi.org/10.1016/S0958-6946(03)00120-1

108. Wang, H.K., Dong, C., Chen, Y.F., Cui, L.M., Zhang, H.P. (2010): A new probiotic Cheddar cheese with high ACE-inhibitory activity and gamma-aminobutyric acid content produced with Koumiss-derived Lactobacillus casei Zhang. Food Technology and Biotechnolology 48, 62-70.

109. Yates, Z., Gunasekaran, K., Zhou, H., Hu, Z., Liu, Z., Ketchem, R.R., Yan, B. (2010): Histidine residue mediates radical-induced hinge cleavage of human $\operatorname{IgGl}$. The Journal of Biological Chemistry 285, 18662-18671. https://doi.org/10.1074/jbc.M110.108597

110. Žilić, S., Akıllıŏlu, G. Serpen, A., Barać, M., Gökmen, V. (2012): Effects of isolation, enzymatic hydrolysis, heating, hydratation and Maillard reaction on the antioxidant capacity of cereal and legume proteins. Food Research International 49, 1-6. https://doi.org/10.1016/j.foodres.2012.06.031

111. Zulueta, A., Maurizi, A., Frigola, A., Esteve, M.J., Coli, R., Burini,G. (2009): Antioxidant capacity of cow milk, whey and deproteinized milk. International Dairy Journal 19, 380-385. https://doi.org/10.1016/j.idairyj.2009.02.003 